\title{
ICEBERGS IN THE NORTH ATLANTIC: \\ MODELLING CIRCULATION CHANGES \\ AND GLACIO-MARINE DEPOSITION
}

\section{Christian Schäfer-Neth}

\section{Research Centre Ocean Margins, University of Bremen, Germany \\ email: csn@uni-bremen.de}

\section{Karl Stattegger}

Institute for Geosciences, University Kiel, Germany

\begin{abstract}
In order to investigate meltwater events in the North Atlantic, a simple iceberg generation, drift, and melting routine was implemented in a high-resolution OGCM. Starting from the modelled last glacial state, every 25th day cylindrical model icebergs 300 meters high were released at 32 specific points along the coasts.

Icebergs launched at the Barents Shelf margin spread a light meltwater lid over the Norwegian and Greenland Seas, shutting down the deep convection and the anti-clockwise circulation in this area. Due to the constraining ocean circulation, the icebergs produce a tongue of relatively cold and fresh water extending eastward from Hudson Strait that must develop at this location, regardless of iceberg origin.
\end{abstract}

From the total amount of freshwater inferred by the icebergs, the thickness of the deposited IRD could be calculated in dependance of iceberg sediment concentration. In this way, typical extent and thickness of Heinrich layers could be reproduced, running the model for 250 years of steady state with constant iceberg meltwater inflow.

\section{INTRODUCTION}

Meltwater events (MWE) during and at the end of the last glaciation led to dramatic changes in the oceanic circulation of the North Atlantic combined with a strong reduction in deepwater formation or even a breakdown of the conveyor belt (Bond, 1995; Bond and Lotti, 1995; Broecker, 1991; Seidov et al., 1996). These changes depend on (i) the amount of freshwater brought in and (ii) the locations of freshwater input and its transport path; that means the conditions to form one or several large freshwater lenses on top of the water column in the central Greenland, Iceland, and Norwegian (GIN) Seas.

Several episodes of rapid discharge of icebergs triggering MWEs are documented by the meltout and sedimentation of debris transported within these icebergs, recognized as coarse grained ice rafted detritus (IRD) and building up the well known Heinrich layers on the seafloor (Heinrich, 1988; Bond et al., 1992; Dowdeswell et al., 1995). 
Recent investigations of Heinrich layers claim major iceberg discharge at the end of the last glaciation (Termination I) mainly from the Hudson Strait drainage basin of the North American Laurentide ice sheet (Dowdeswell et al., 1995; Andrews et al., 1994; Grousset et al., 1993) and to a minor extent from the breakdown of the Barents ice sheet (Bischof, 1994; Rosell-Melé and Koç, 1997; Svendsen et al., 1996; Vorren et al., 1990). On the other hand, numerical experiments demonstrate clearly that a significant weakening of the conveyor belt predominantely would take place if a major freshwater injection entered the northern North Atlantic (NNA) from the northeast caused by the breakdown of the Barents-shelf ice sheet (Schäfer-Neth and Stattegger, 1997).

In this study, we present OGCM based numerical experiments of the release, transport and melting of icebergs from various sources along the NNA margins. Starting scenario is the Last Glacial Maximum (LGM) stage which has been modelled successfully by Schäfer-Neth (1994, 1998; Haupt et al., 1994).

\section{THE OCEAN CIRCULATION MODEL}

For the experiments, we use SCINNA ("Sensitivity and Circulation of the Northern North Atlantic", Schäfer-Neth, 1994), a three-dimensional prognostic Ocean General Circulation Model employing the primitive equations that is based on the Modular Ocean Model by Pacanowski et al. (1993). On a rotated spherical grid where the model's north pole is located at $180 \mathrm{~W} / 30 \mathrm{~N}$, the model domain covers the GIN Seas and parts of the neighboring basins (Fig. 3). The horizontal grid spacing is 0.5 degrees $(\approx 55 \mathrm{~km})$ in latitude and longitude, and vertically there are 17 levels with thicknesses increasing from $50 \mathrm{~m}$ at the top to $1000 \mathrm{~m}$ at the bottom of the deepest basins, enabling a realistic representation of topography. Test runs forced with modern sea surface temperatures, salinities, and wind stress reproduced the modern oceanography reasonably well (Haupt et al., 1994, 1995). After aiding the paleoceanographic reconstruction of the LGM, that is, to reconstruct physically consistent temperature and salinity distributions with the associated circulation patterns from the proxy data (Schäfer-Neth, 1994, 1998), SCINNA is now applied to study the deglaciation phases since the LGM.

\section{IDEALIZED ICEBERGS}

Real icebergs exist in a great variety of sizes and shapes that are too complex to be implemented in a general circulation model. Instead, to keep the model code simple and to save computation time, icebergs are implemented as idealized pie-shaped blocks of ice (Fig. 1). The iceberg portion above water is neglected (i) because it is generally small compared to the immersed part, and (ii)

because for typical water and wind velocities water drag is generally the most important force acting upon an iceberg (cf. White et al., 1980; equation (31) for typical wind and water velocities; Matsumoto, 1996). Due to the high ice albedo, the iceberg's heat gain from atmosphere and solar irradiation (below $100 \mathrm{Wm}^{-2}$; Lemke et al., 1989) is much smaller than the heat fluxes (Fig. 


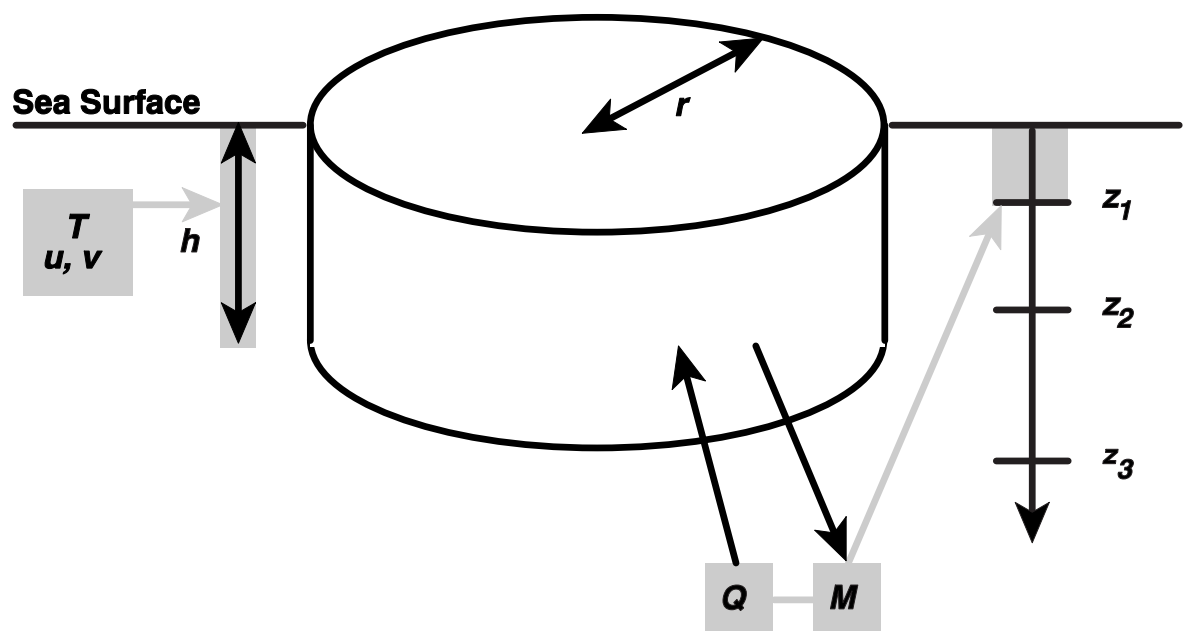

Figure 1: In the model, icebergs are represented by idealized pie-shaped blocks of ice. Explanation of symbols: $T=$ water temperature, $u, v=$ horizontal velocities, $h, r=i$ ceberg height and radius, $Q=$ heat flowing from water into ice, $M=$ meltwater runoff from iceberg to water, and $z_{1 \ldots 3}=$ depths of model layer interfaces.

2) from the surrounding water (Russel-Head, 1980). Therefore the heat exchange at the iceberg top is neglected, too.

In the current implementation, icebergs of predefined height $h$ and radius $r$ (Fig. 1) are released at prescribed locations in fixed time intervals. Once an iceberg has been generated, its drift and decay are computed as follows. First, the horizontal velocities are averaged from the model grid over the total iceberg height (Fig. 1, shaded boxes to the left) to the current location of the iceberg. The new position of the iceberg is then calculated by

$$
\left(\begin{array}{l}
\lambda \\
\phi
\end{array}\right)^{\text {new }}=\left(\begin{array}{l}
\lambda \\
\phi
\end{array}\right)^{\text {old }}+\text { Time Step } \times \frac{180}{\pi \text { Earth Radius }}\left(\begin{array}{c}
\bar{u} \cos \phi^{\text {old }} \\
\bar{v}
\end{array}\right),
$$

where $\lambda$ and $\phi$ denote longitude and latitude, respectively, and the averaged zonal and meridional velocities are denoted by $\bar{u}$ and $\bar{v}$. We favour this Lagrangian approach because it more clearly reveals how the ocean might respond to swarms of individual icebergs than an Eulerian technique. The latter would have to be implemented in a similar fashion as one of the commonly used sea ice models, using some measure of iceberg coverage as a tracer. This would require a high diffusion to maintain numerical stability, which can be expected to broaden the iceberg drift paths and to yield results more closely to those obtained with pure meltwater inputs.

Like $\bar{u}$ and $\bar{v}$, the average temperature $\bar{T}$ at the iceberg position is computed from the surrounding model grid points, thus yielding the iceberg's melt rate $\mu$ by the empirical relation from tank experiments:

$$
\mu=0.018(\bar{T}+1.8)^{1.5}
$$

(Fig. 2; Russel-Head, 1980). Then the iceberg's new dimensions are given by

$$
\left(\begin{array}{l}
h \\
r
\end{array}\right)^{\text {new }}=\left(\begin{array}{l}
h \\
r
\end{array}\right)^{\text {old }}-\text { Time Step } \times \mu .
$$


If either height or radius shrink below a certain limit ( $25 \mathrm{~m}$ for the current study), the assumption of an iceberg predominantly influenced by the surrounding waters is no longer met and the iceberg is completely removed from the system.

The change of the iceberg volume is proportional (i) to the mass of freshwater added to the ocean (Fig. 1):

$$
M=\rho_{i c e} \pi\left[\left(h r^{2}\right)^{\text {old }}-\left(h r^{2}\right)^{\text {new }}\right],
$$

and (ii) the amount of heat taken from the ocean required for melting the ice:

$$
Q=\kappa_{i c e} M
$$

with the ice density $\rho_{i c e}=0.91 \mathrm{~g} / \mathrm{cm}^{3}$ and the heat of fusion $\kappa_{i c e}=334 \mathrm{~J} / \mathrm{g}$. These heat and freshwater fluxes lead to a temperature and salinity stratification in the ultimate vicinity of the iceberg (Foldvik et al., 1980; Ohshima et al., 1994) that can not be resolved in the circulation model. Assuming that the meltwater ascends along the iceberg's sides and spreads at the sea surface, the fluxes are applied over the entire top level of the model grid box containing the iceberg (Fig. 1, shaded boxes to the right).

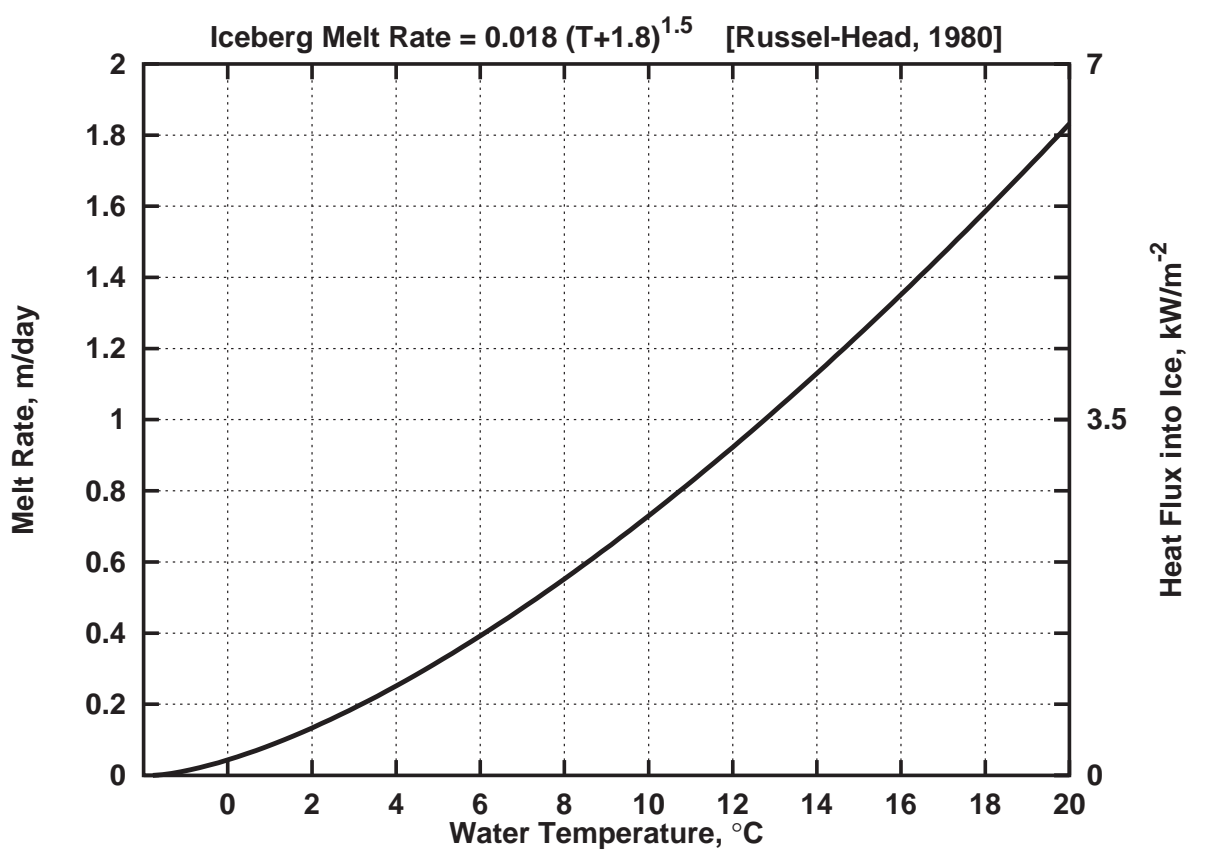

Figure 2: Iceberg decay as function of water temperature, after laboratory experiments by Russel-Head (1980).

Apart from the water to ice heat transfer, there are many processes that may deteriorate an iceberg, such as wave erosion, calving of overhanging ice, wind-induced convection, and heat transfers induced by water flows relative to the ice (White et al., 1980). These processes that increase the ice melt rate can not be resolved by the circulation model used here and must therefore be parameterized. For the experiment discussed here in further detail, the melt rate was computed according to equations (2) and (3). To examine the consequences of the additonal 
deterioration mechanisms, we repeated this experiment with a 10-fold melt rate increase: $\mu=$ $0.18(\bar{T}+1.8)^{1.5}$. Although this is a substantial change, the resulting circulation patterns and temperature-salintity distributions did not change very much, except for strengthened density gradients and intensified currents.

\section{EXPERIMENTS AND RESULTS}

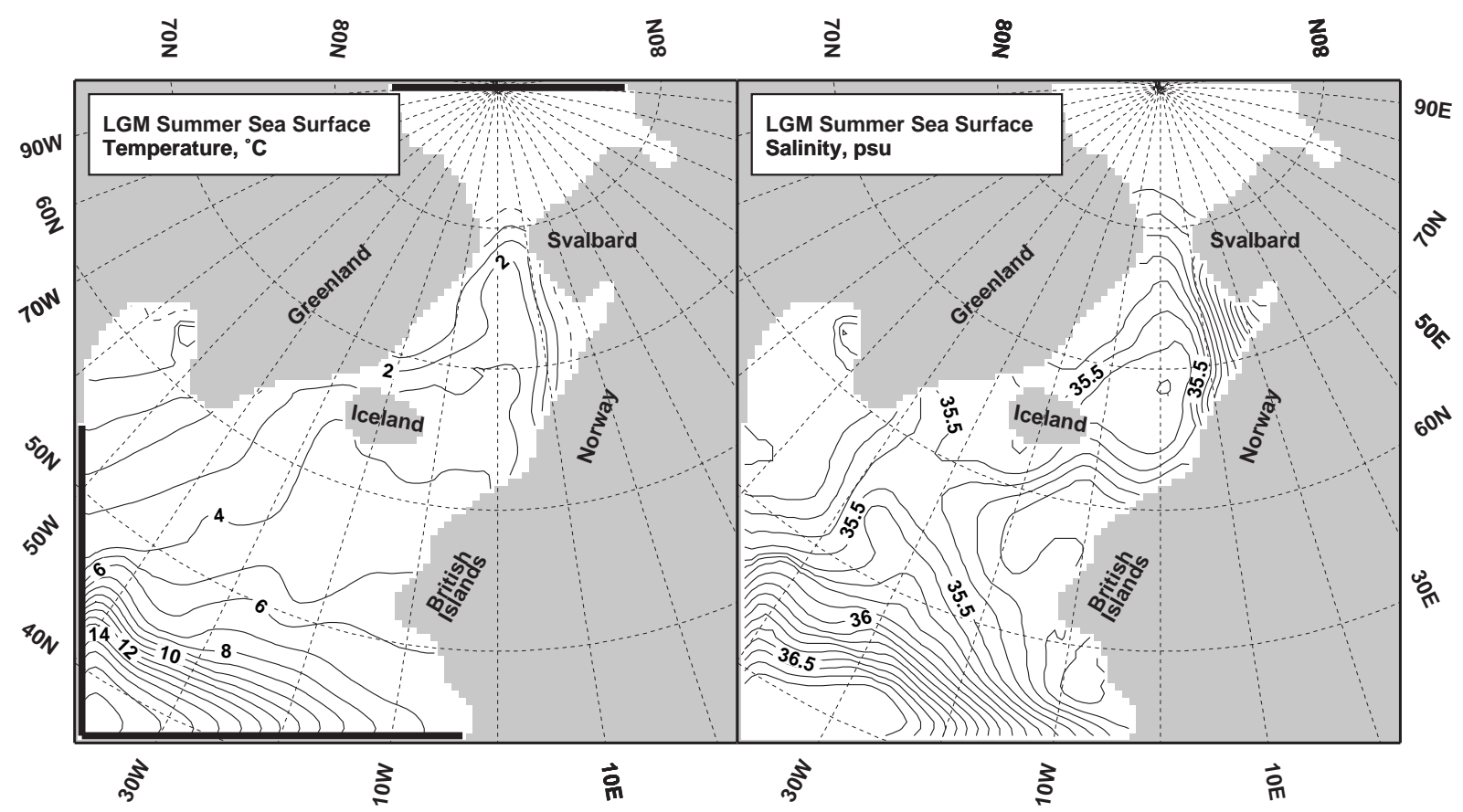

Figure 3: Sea surface temperature (left) and salinity (right) for the glacial summer, reconstructed from sediment-core based temperature estimates and oxygen isotope measurements (Schäfer-Neth, 1994, 1998). The coastline differs from the modern due to the lower glacial sea level. Contour intervals: $1^{\circ} \mathrm{C}$ and 0.1 psu. Heavy black lines along the southwestern and northern boundaries indicate restoring zones.

\subsection{The Experiments}

Our experiments are based on the reconstructed glacial summer scenario (Schäfer-Neth, 1994, 1998), the time slice being best documented by sediment core measurements. To arrive at this scenario, SCINNA was driven by restoring to sea surface temperatures reconstructed from faunal assemblages (Weinelt et al., 1996, Pflaumann et al., 1996) and estimates of sea surface salinities derived from these temperatures and oxygen isotope measurements taken from various publications. For wind forcing, a glacial wind field modelled with the ECHAM T42 atmospheric model (Hoffmann, pers. comm.) using the same temperature data as bottom boundary conditions. With these forcing data sets, SCINNA was spun up for some 400 years. The resulting temperature, salinity, density, and velocity distributions exhibit a glacial summer scenario that is quite similar to modern winter conditions, comprising a relatively warm and salty surface inflow (Figs. 3, 4 left) from the Atlantic into the Norwegian Sea that is balanced by outflows via the East Greenland Current and a deep overflow over the Iceland-Scotland Ridge (Fig. 4 right), and a 
formation of deep water in the GIN Seas (Fig. 5). These three-dimensional fields were extracted for initialization and $T / S$ restoring (Fig. 3) at the southwestern and northernmost boundaries of the meltwater and iceberg experiments.

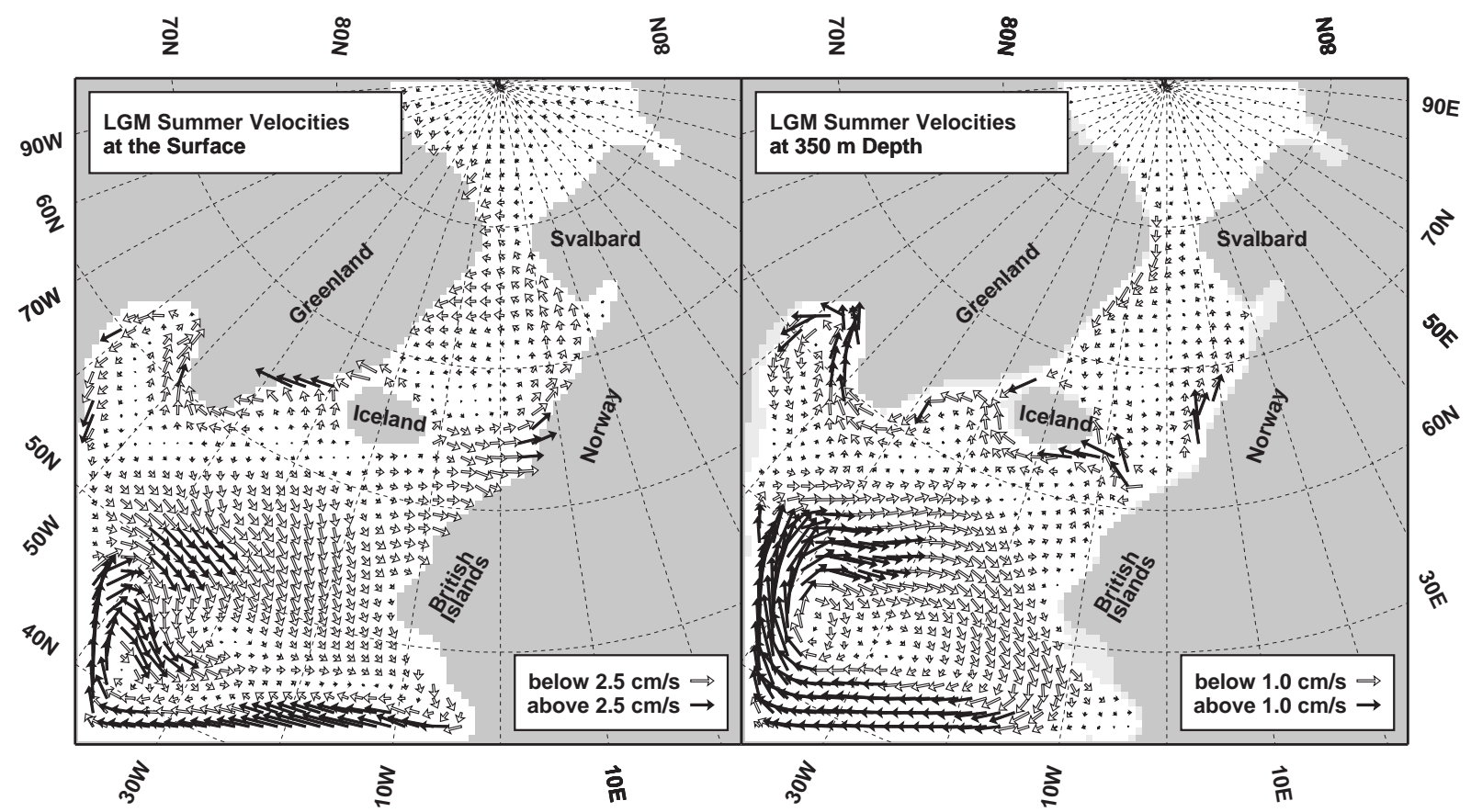

Figure 4: Modelled glacial summer circulation at the surface (left) and $350 \mathrm{~m}$ depth (right). Only one vector in two is displayed for clarity. The currents, especially the flows into and out of the GIN Seas, are quite similar to modern conditions.

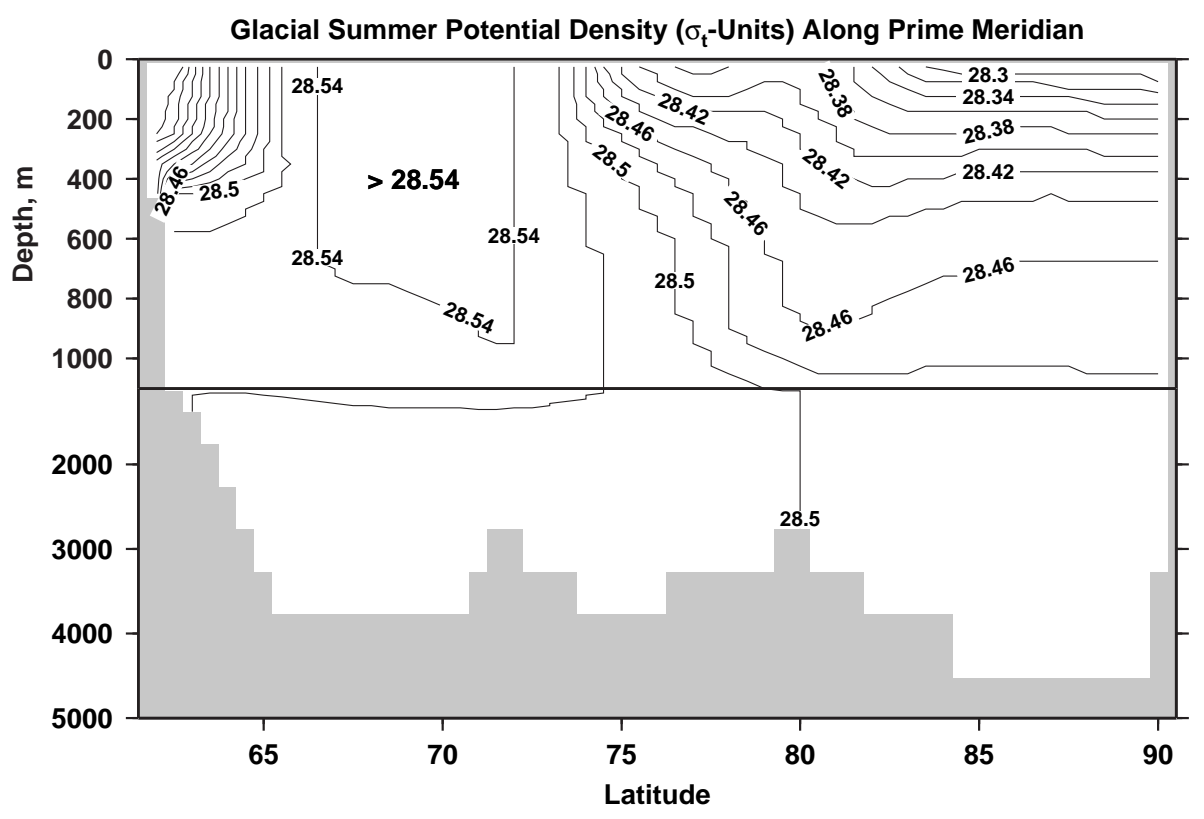

Figure 5: Meridional section of potential density along Prime Meridian for the glacial reconstruction. At about $69 \mathrm{~N}$, there is a chimney of dense water with $\sigma_{t} \geq 28.54 \mathrm{gcm}^{-3}$ extending from the surface down to $1200 \mathrm{~m}$. In resemblance to modern conditions, this gives clear evidence of deep convection. Contour interval: $0.02 \mathrm{~g} / \mathrm{cm}^{3}$. 
For forcing the meltwater studies, we used the surface heat and freshwater fluxes that were diagnosed from the LGM scenario and modified by additional freshwater sources along the margins of the glacial ice sheets of Labrador, Greenland, and/or Europe. Depending on the source area of the meltwater input, the ocean reacts in two distinctly different ways (SchäferNeth and Stattegger, 1997): If the meltwater originates from Greenland only, even intense pulses of $1 \mathrm{~Sv}\left(=10^{6} \mathrm{t} / \mathrm{s}\right)$, which are equivalent to a complete melting of the present-day Greenland ice within about 200 years, cause no major change in the current system except for an strengthening of the East Greenland Current. On the other hand, meltwater from the European coast has severe effects. By shifting the warm and salty inflow away from Britain over to Iceland, they can spread over the whole GIN Seas, thereby stopping the deep water formation in this region and pushing the circulation from its normal cyclonal-antiestuarine into an anticyclonal-estuarine mode.

Our iceberg experiments extend these meltwater studies and address the following questions: (i) Do icebergs cause circulation changes comparable to those induced by continental meltwater runoff? (ii) Can Heinrich events be simulated with SCINNA, and what are their consequences for the ocean circulation? (iii) Can the IRD deposits in Heinrich layers be correlated with distinct iceberg source regions?

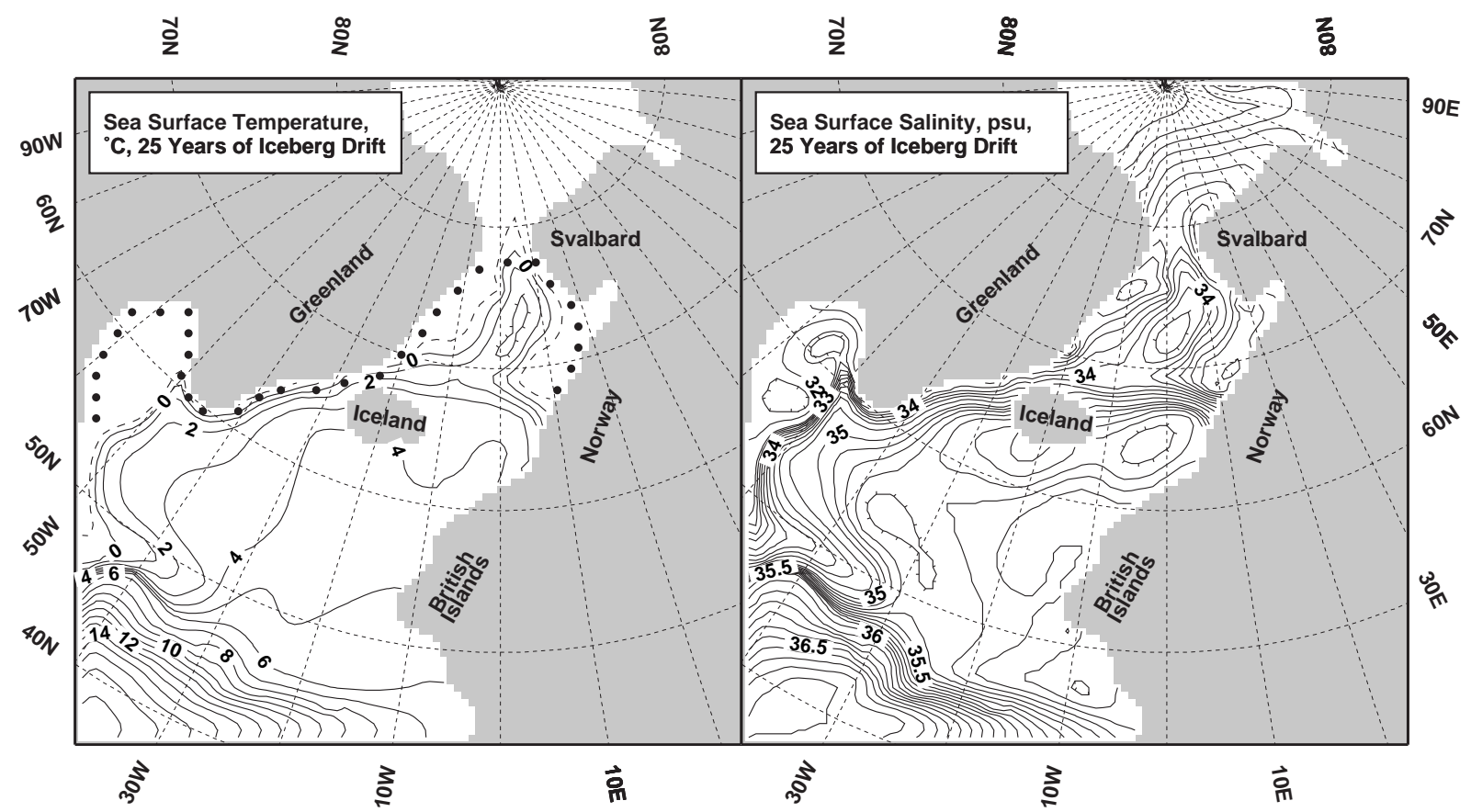

Figure 6: After 25 years of integration with icebergs, both sea surface temperature (left) and salinity (right) are greatly reduced all over the Greenland, Norwegian, and Labrador Seas, and a cold and fresh tongue extends towards Europe along $50 \mathrm{~N}$. Contour intervals: $1{ }^{\circ} \mathrm{C}, 1$ psu below 33, 0.2 psu between 33 and 35, and 0.1 psu above 35 psu. Dots indicate iceberg generation locations.

To summarize the results of numerous experiments with different regions and intensities of iceberg input, we discuss here one study in which icebergs were released at the coasts of Europe, Greenland, and Labrador. In this experiment, every 25th day a huge iceberg of $300 \mathrm{~m}$ height 
and $5 \mathrm{~km}$ radius was launched at each of the 32 locations marked by dots in Fig. 6. On average, this amounts to a $0.29 \mathrm{~Sv}$ input of ice. For comparison, height estimates for the glacial ice dome over the Barents Sea range from 1000 m (Peltier, 1994) to 3400 m (Lambeck, 1997). Taking 2000 m as a mean value yields (Saltzman and Verbitzky, 1992; equation (8)) an ice mass of about $3 \cdot 10^{16} \mathrm{t}$, and a melting of this mass over 2000 years would result in a meltwater input of almost $0.5 \mathrm{~Sv}$.

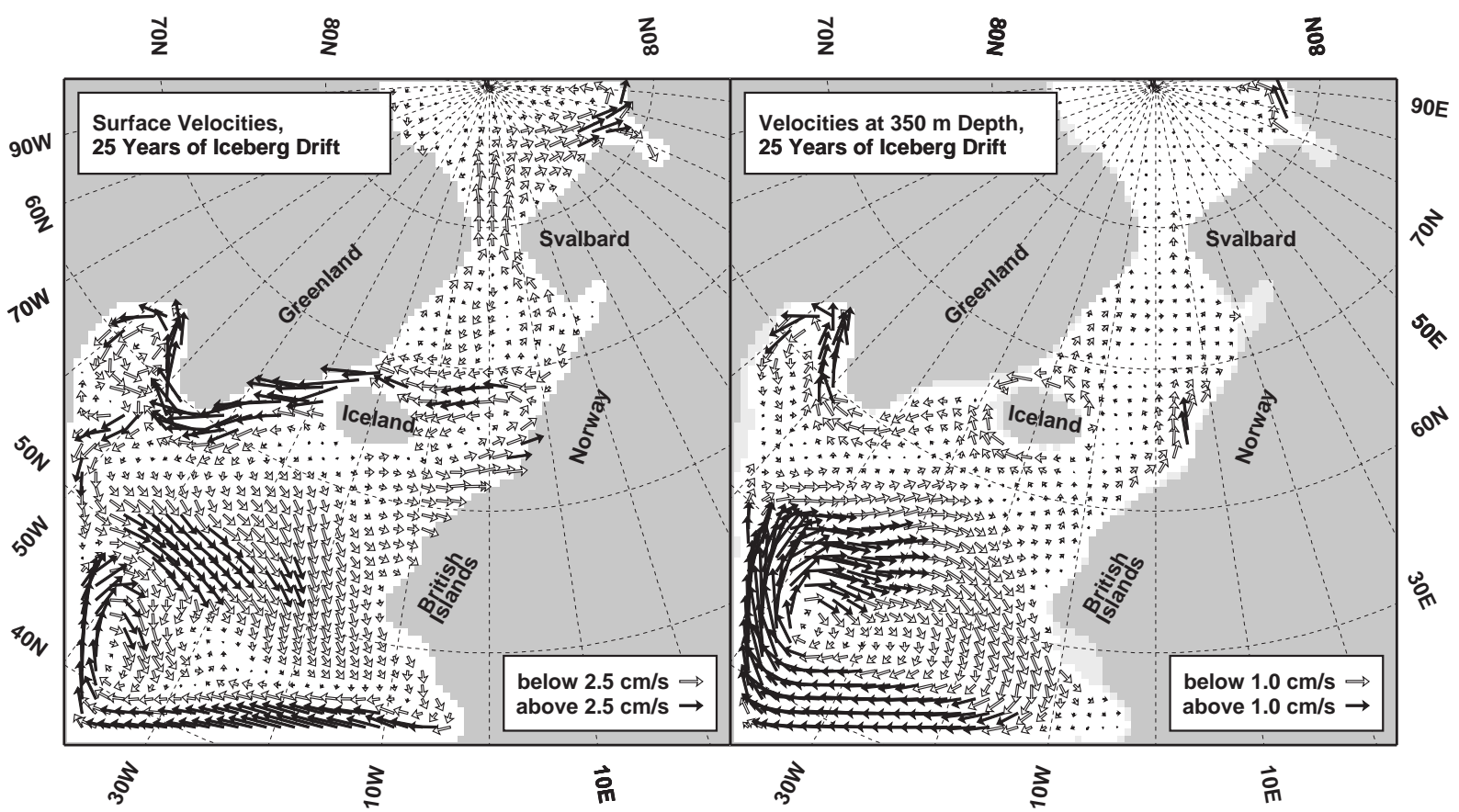

Figure 7: Under the influence of drifting and melting icebergs, the current system changes drasticllay in the GIN Seas. Instead of feeding a basin-wide cyclone, the inflow from the Atlantic turns westward towards Iceland (left). The deep outflow over the Iceland-Scotland Ridge ceases, and a weak inflow can be found instead (right). The circulation of the North Atlantic, however, is hardly affected by the meltwater, except for intensified currents around the southern tip of Greenland and in the Labrador Sea.

The lifetime of the icebergs is highly variable, depending on water temperature. Icebergs entering warmer regions at about $50 \mathrm{~N}$ decay within 2-4 years, whereas those transported to polar regions with freezing conditions may last for some decades. Of course, the distribution of warmer and colder areas changes with time, because the icebergs comprise a heat sink that is not fixed in space. After about 20 years, the model reaches a new steady state with almost all icebergs going to regions warm enough for a complete melting, yielding a constant freshwater input of $0.25 \mathrm{~Sv}$ that is compensated by the boundary restoring zones.

\subsection{Iceberg-induced circulation changes}

This new state is marked by distinctly decreased temperatures (Fig. 6 left) reaching the freezing point in the Labrador Sea and at the coasts of Greenland and Norway. The salinitiy is lowered to values of $30 \mathrm{psu}$ in these regions (right), and in the central GIN Seas it drops by 0.8 to 34.2 psu. Most prominent are the front from Norway to Iceland along $67 \mathrm{~N}$ and the cold low-salinity 
tongue pointing from Canada to Europe at $50 \mathrm{~N}$.

The front corresponds to a strong westward current (Fig. 7 left) north of Iceland. As a shortcut of the GIN Seas cyclone (Fig. 4 left), this current isolates the GIN Seas very effectively from the warmer North Atlantic and feeds an intensified East Greenland Current. In the Greenland Sea, the fomerly existing cyclone is replaced by an anticyclone. At $350 \mathrm{~m}$ depth (Fig. 7 right), the outflow from the GIN Seas (Fig. 4 right) has stopped and instead a weak inflow has been established. This reversal is linked to the salinity reduction at the surface that causes the deep water formation to stop (Fig. 8). These changes were found as well in additional experiments with icebergs originating at the European coasts only, whereas studies with icebergs released only around Greenland showed essentially unmodified circulation patterns, except for a stronger East Greenland Current. Thus the eastern part of the GIN Seas can be regarded as the region most sensitive to massive iceberg generation. In addition, icebergs from this area seem to be more effective than pure meltwater inputs of equivalent amount. According to our numerical experiments, a meltwater inflow of $0.1 \mathrm{~Sv}$ hardly affects the circulation, but an equivalent production of icebergs clearly does - in the results shown here, only $0.06 \mathrm{~Sv}$ come from the icebergs released near Europe.

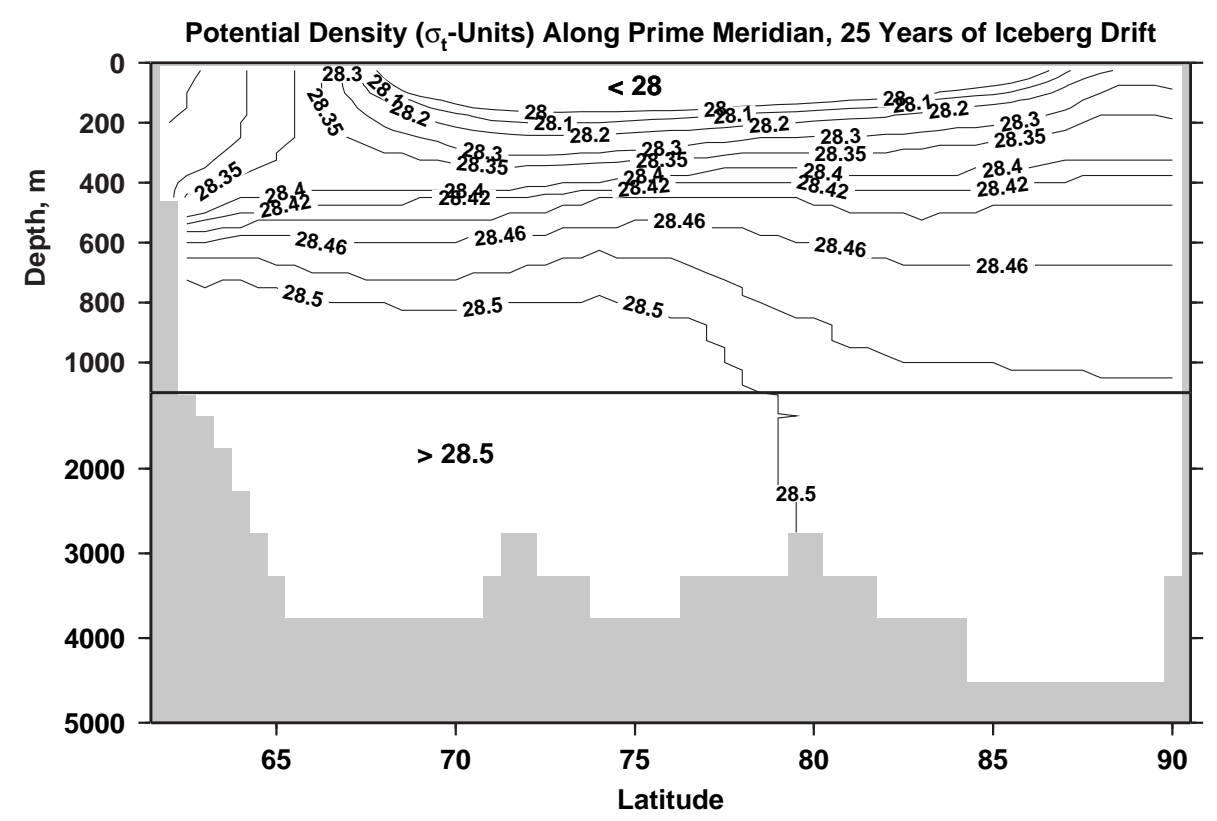

Figure 8: Meridional potential density section along Prime Meridian for the iceberg experiment. The melting icebergs impose a lid of relatively fresh water over the GIN Seas and stop the convection there. Contour interval: $0.02 \mathrm{~g} / \mathrm{cm}^{3}$.

The tongue of cold and fresh surface waters corresponds remarkably well with the distribution of IRD found in Heinrich layers (Bond et al., 1992, Dowdeswell et al., 1995). In the experiment presented here, the icebergs do not drift past $30 \mathrm{~W}$, but other experiments with higher iceberg input (above $0.5 \mathrm{~Sv}$ ) in the Labrador Sea produced iceberg tracks ending at the eastern Atlantic coast. In these mid-latitudes, there is some tendency of the icebergs to focus their tracks onto 


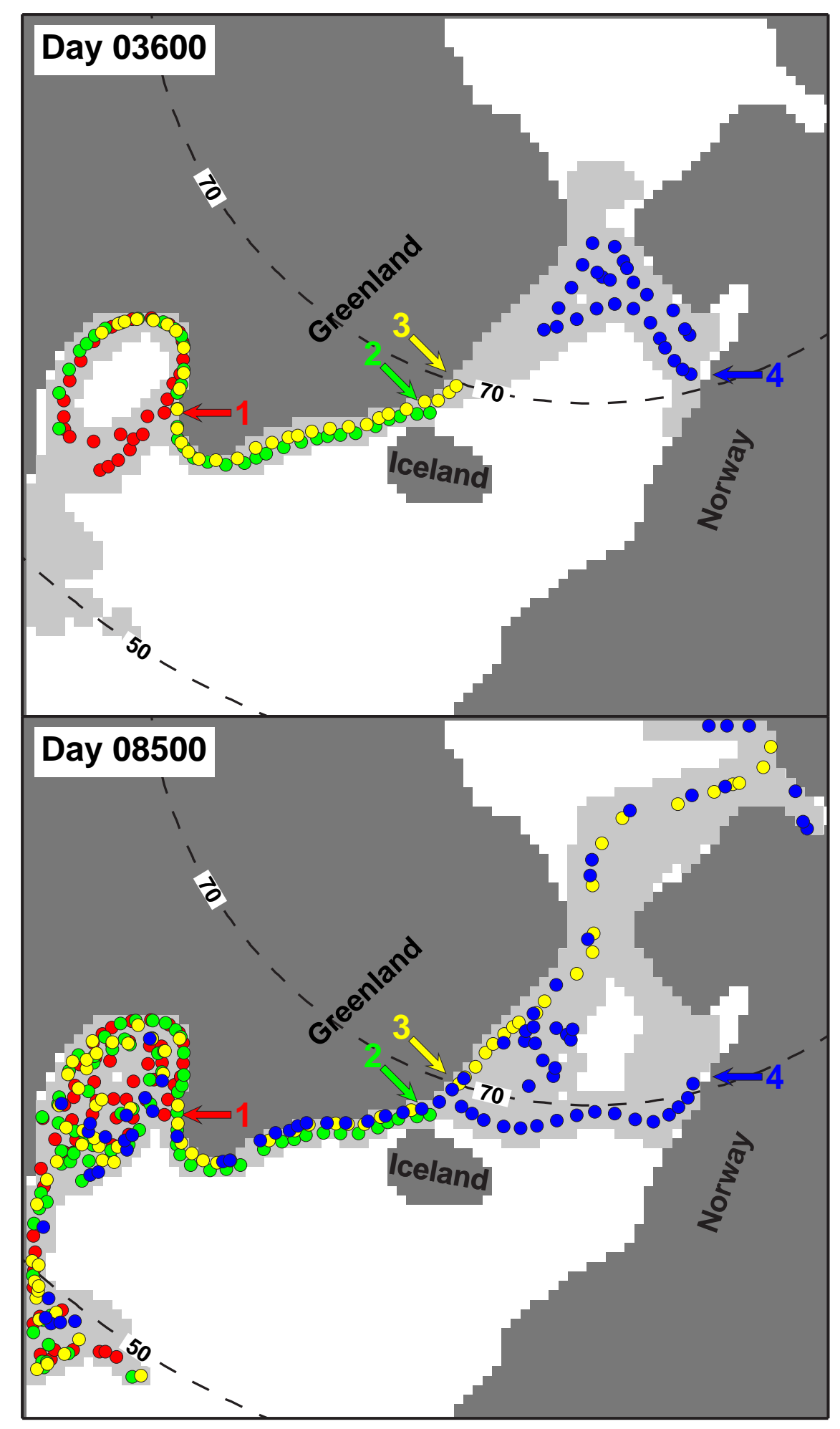

Figure 9: Tow snapshots of iceberg positions after 3600 (top panel) and 8500 (bottom) days. Model grid boxes containing icebergs are marked by light shading. Dots denote the positions of icebergs released at four different locations that are identified by the colored arrows. At day 3600, the drift paths are clearly correlated with the respective source regions. This is not valid any more a couple of years later. Although the icebergs launched at location 2 (green) still drift towards Labrador, those starting nearby at location 3 (yellow) have developed an additional branch entering the Arctic. Similarly, icebergs from the Barents shelf (blue) can be found everywhere. It should be noted, too, that icebergs from all sources reach the tongue at $50 \mathrm{~N}$. 
a distinct path. This is due to the meltwater release along the track that reinforces the density gradient which defines the current axis. That is, given the subtropical and subpolar gyres, the icebergs can not do anything but drift eastward along about $50 \mathrm{~N}$, regardless of their origin. To illustrate this, Fig. 9 shows two snapshots of iceberg locations at integration day 3600 (top) and 8500 (bottom). The positions of icebergs released at four different locations (colored arrows) are displayed. At day 3600, it is easy to tell which iceberg came from what starting point, but at day 8500, icebergs from all starting points have reached $50 \mathrm{~N}$. This is consistent with the results of Robinson et al. (1995), who reconstructed iceberg paths from magnetic susceptibility. The iceberg movements are very irregular. Especially near the Barents Sea and northeast of the Denmark Strait, they sometimes form swarms about the size of Iceland. Due to the local salinity minimum associated with these swarms, they rotate anticyclonally, gathering nearby icebergs and releasing them randomly. This randomness becomes very clear when comparing the distributions of green and yellow points in the lower panel of Fig. 9. As indicated by the respective arrows, source locations 2 (green) and 3 (yellow) are very close, but still icebergs from 3 drift in two opposite directions, whereas those from 2 go only to the west. The tracks starting at location 4 (blue) are split into a westward and a northward branch, too. Gwiazda et al. (1996 $\mathrm{a}, \mathrm{b})$, who examined the possible origin of IRD found in Heinrich layers 2 and 3, tracked parts of the IRD back to even Scandinavia. Thus the chaotic iceberg movements must be regarded not as a specific feature of the model but as a realistic behaviour.

\subsection{Sedimentation of Heinrich layers}

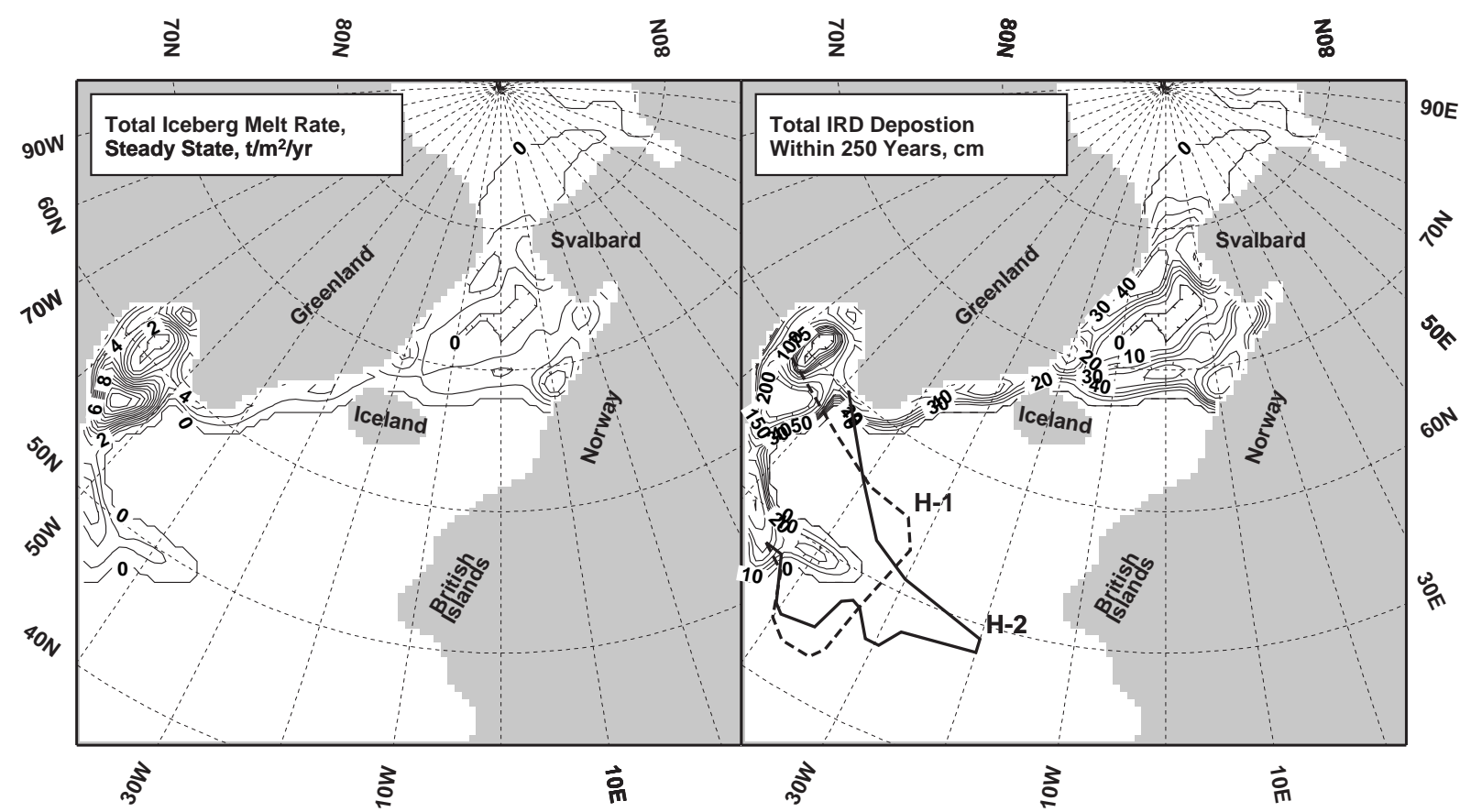

Figure 10: Distribution of steady state iceberg melt rates (left) and deduced thickness (right) of the IRD layer deposited within 250 years using a sediment concetration of $1 \%$. Contour intervals: left $1 \mathrm{t} / \mathrm{m}^{2} / \mathrm{yr}$, right $10 \mathrm{~cm}$ below 50, $25 \mathrm{~cm}$ between 50 and 100, and $50 \mathrm{~cm}$ above $100 \mathrm{~cm}$. Heavy dashed and solid lines: $10 \mathrm{~cm}$ isopachs of Heinrich layer 1 and 2 after Dowdeswell et al. (1995). 
From the melting experiments we get an average melting rate and freshwater influx from icebergs (Fig. 10 left). By adding sediment of coarse silt or coarser size to the melting ice which sinks down rapidly without much lateral transport, we can produce IRD layers on the sea floor. The thickness of these IRD layers is governed by (i) the transport paths of icebergs, (ii) the melting rate dependent on seawater temperature, and (iii) the concentration of initial iceberg sediment load.

The sediment load of an iceberg is concentrated mainly in the basal part (Dowdeswell and Murray, 1990), most probably within the lowermost 10 meters. Here, the maximum sediment concentration may reach up to $10 \%$ of the total volume, yielding average sediment concentrations of $1 \%$ in icebergs of $100 \mathrm{~m}$ height, $0.5 \%$ for $200 \mathrm{~m}$, and so on. However, in the experiment presented here, the initial height was fixed to $300 \mathrm{~m}$ for all icebergs, giving a maximum concentration of about $0.3 \%$. To account for the natural variability, we adopted a mean overall sediment content of $0.1 \%$ for our estimation of IRD deposition. A uniform distribution of IRD within the ice is consistent with the model results of Matsumoto (1996), who could not appropriately simulate the IRD sedimentation during isotope stage 5e by confining the sediment load to the base of the icebergs, but had to use an almost uniform distribution. However, the IRD layer thickness not only depends on the amount and distribution of sediment within the ice, but as well on the duration of a Heinrich event.

Running the model for 250 years of steady state with constant iceberg meltwater inflow (see above notes on the steady state), that is within the estimates of Heinrich event durations (Andrews et al., 1994; Manighetti et al., 1995), we yield the characteristic distribution pattern of IRD shown in Fig. 10. This figure contains also the $10 \mathrm{~cm}$ isopachs of Heinrich layer 1 and 2 from Dowdeswell et al. (1995) for comparison. The modelled IRD distribution exhibits a tongue extending eastward along $50 \mathrm{~N}$, resembling the natural distributions. The modelled tongue, however, is quite short, especially compared to H-2. According to our other model experiments with icebergs of different initial heights, the maximum extent of the modelled IRD belt critically depends on iceberg height. Higher icebergs can travel far more eastward and eventually reach the European continent. Thus, good estimates of typical post-glacial iceberg dimensions are essential for a realistic simulation of Heinrich events. Intercomparison of numerical model results and sediment core data will help to reconstruct typical dimensions of the icebergs that were released during the Heinrich event.

\section{CONCLUSIONS}

It has been shown that melting icebergs have similar effects on the circulation system as pure meltwater inputs from the coasts. Especially the different circulation changes caused by icebergs from Europe or Labrador are comparable. However, icebergs can be more effective than continental meltwater runoff because they are moving sources of freshwater. They can transport 
freshwater over a long distance and subsequently release it within a small area. Thus the region of meltwater input by icebergs can be more confined than it is the case with continental runoff, yielding a more severe influence on density field and circulation.

These first experiments using freely drifting and melting icebergs gave promising results for further modelling of Heinrich events. Both extent and thickness of the Heinrich layers could be approximately reproduced. Sensitivity studies with different iceberg sizes and production rates will yield estimates of typical iceberg dimensions and freshwater inputs during the Heinrich events.

According to our results, icebergs can drift from a given source region to almost any place in the North Atlantic. Thus, to fully understand Heinrich events, it should not only be mapped where IRD was deposited, it is equally important to determine where the material came from.

Due to the temperature decrease by the icebergs the heat flux from ocean to atmosphere must be reduced, and it might be argued that this should be included in the surface forcing fields of the experiments. In the present study, the heat loss to ice was generally of the same order of magnitude as the surface heat flux or even larger, and a surface heat flux reduction would not have had significant effects. This would be even more the case if additional iceberg deterioration

mechanisms (White et al., 1980) were included in the model, thereby causing higher heat loss of the ocean to the icebergs.

\section{ACKNOWLEDGEMENTS}

We wish to thank A. Paul for his thorough and fruitful review. This work was supported by the Deutsche Forschungsgemeinschaft within the framework of Sonderforschungsbereich 313, University Kiel.

\section{REFERENCES}

Andrews, J. T., Erlenkeuser, H., Tedesco, K., Aksu, A., and Jull, A. (1994) Late Quaternary (Stage 2 and 3) Meltwater and Heinrich Events, Northwest Labrador Sea. Quaternary Research, 41: 26-34.

Bischof, J. (1994) The Decay of the Barents Ice Sheet as Documented in Nordic Seas Ice-Rafted Debris. Marine Geology, 117, 35-55.

Bond, G. C. and 13 others. (1992) Evidence for Massive Discharges of Icebergs into the North Atlantic Ocean During the Last Glacial Period. Nature, 360: 245-249.

Bond, G. C. (1995) Climate and Conveyor. Nature, 377: 383-384.

Bond, G. C. and Lotti, R. (1995) Iceberg Discharges into the North Atlantic on Millenial Time Scales During the Last Glaciation. Science, 267: 1005-1009. 
Broecker, W. S. (1991) The Great Ocean Conveyor. Oceanography, 1: 79-89.

Dowdeswell, J. A. and Murray, T. (1990) Modelling Rates of Sedimentation from Icebergs. In Dowdeswell, J. A. and Scourse, J. C., eds., Glacimarine Environments: Processes and Sediments. Geological Society of London Special Publication, 53: 121-137.

Dowdeswell, J. A., Maslin, M., Andrews, J., and McCave, I. N. (1995) Iceberg Production, Debris Rafting, and the Extent and Thickness of Heinrich Layers (H-1, H-2) in North Atlantic Sediments. Geology, 23: 301-304.

Foldvik, A., Gammelsrød, T., and Gjessing, Y. (1980) Flow Around Icebergs. Annals of Glaciology, 1: $67-70$.

Grousset, F. E., Labeyrie, L., Sinko, J., Cremer, M., Bond, G., Duprat, J., Cortijo, E., and Huon, S. (1993) Patterns of Ice-Rafted Detritus in the Glacial North Atlantic $\left(40-55^{\circ} \mathrm{N}\right)$. Paleoceanography, 8: 175-192.

Gwiazda, R. H., Hemming, S., and Broecker, W. (1996 a) Tracking the Sources of Icebergs with Lead Isotopes: The Provenance of Ice-Rafted Debris in Heinrich Layer 2. Paleoceanography, 11: 77-93.

Gwiazda, R. H., Hemming, S., and Broecker, W. (1996 b) Provenance of Icebergs During Heinrich Event 3 and the Contrast to their Sources During Other Heinrich Episodes. Paleoceanography, 11: 371-378.

Haupt, B. J., Schäfer-Neth, C., and Stattegger, K. (1994) Modelling Sediment Drifts; A Coupled Oceanic Circulation-Sedimentation Model of the Northern North Atlantic. Paleoceanography, 9: 897-916.

Haupt, B. J., Schäfer-Neth, C., and Stattegger, K. (1995) Three-Dimensional Numerical Modelling of Late Quaternary Paleoceanography and Sedimentation in the Northern North Atlantic. Geologische Rundschau, 84: 137-150.

Heinrich, H. (1988) Origin and Consequences of Cyclic Ice-Rafting in the Northeast Atlantic Ocean During the Past 130,000 Years. Quaternary Research, 29: 142-152.

Lambeck, K. (1996) Limits on the Areal Extent of the Barents Sea Ice Sheet in Late Weichselian Time. Global and Planetary Change, 12: 41-51.

Lemke, P., Owens, W., and Hibler III, W. (1989) A Coupled Sea Ice-Mixed Layer-Pycnocline Model for the Weddell-Sea. Report Max-Planck-Institut für Meteorologie Hamburg, 28: 26 pp.

Manighetti, B., Maslin, M., McCave, I. N., and Shackleton N. (1995) Chronology for Climate Change: Developing Age Models for the BOFS Cores. Paleoceanography, 10: 513-526. 
Matsumoto, K. (1996) An Iceberg Drift and Decay Model to Compute the Ice-Rafted Debris and Iceberg Meltwater Flux: Application to the Interglacial North Atlantic. Paleoceanography, 11: 729-742.

Ohshima, K. I., Kawamura, T., Takizawa, T., and Ushio, S. (1994) Step-Like Structure in Temperature and Salinity Profiles, Observed near Icebergs Trapped by Fast Ice, Antarctica. Journal of Oceanography, 50: 365-372.

Pacanowski, R., Dixon, K. D., and Rosati, A. (1993) The G.F.D.L Modular Ocean Model Users Guide. GFDL Ocean Group Technical Report No. 2, Geophysical Fluid Dynamics Laboratory / NOAA, Princeton University.

Peltier, W. R. (1994) Ice Age Paleotopography. Science, 265: 195-201.

Pflaumann, U., Duprat, J., Pujol, C, and Labeyrie, L. (1996) SIMMAX, a Transfer Technique to Deduce Atlantic Sea Surface Temperatures from Planctonic Foraminifera - the "EPOCH" Approach. Paleoceanography, 11: 15-35.

Robinson, S. G., Maslin, M., and McCave, I. N. (1995) Magnetic Susceptibility Variations in Upper Pleistocene Deep-Sea Sediments of the NE Atlantic: Implications for Ice Rafting and Paleocirculation at the Last Glacial Maximum. Paleoceanography, 10: 221-250.

Rosell-Melé, A. and Koç, N. (1997) Paleoclimatic Significance of the Stratigraphic Occurrence of Photosynthetic Biomarker Pigments in the Nordic Seas. Geology, 25: 49-52.

Russel-Head, D. S. (1980) The Melting of Free-Drifting Icebergs. Annals of Glaciology, 1: 119122.

Saltzman, B. and Verbitzky, M. Y. (1992) Astenospheric Ice-Load Effects in a Global DynamicalSystem Model of the Pleistocene Climate. Climate Dynamics, 8: 1-11.

Schäfer-Neth, C. (1994) Modellierung der Paläoozeanographie des nördlichen Nordatlantiks zur Zeit der letzten Maximalvereisung. PhD Thesis, University of Kiel, Germany, 105pp.

Schäfer-Neth, C. (1998) Changes in the Seawater Salinity-Oxygen Isotope Relation Between Last Glacial and Present: Sediment Core Data and OGCM Modelling. Paleoclimates, 2(23): $101-131$

Schäfer-Neth, C. and Stattegger, K. (1997) Meltwater Pulses in the Northern North Atlantic: Retrodiction and Forecast by Numerical Modelling. Geologische Rundschau, 86: 492-498

Seidov, D., Sarnthein, M., Stattegger, K., Prien, R., and Weinelt, M. (1996) North Atlantic Ocean Circulation During the Lat Glacial Maximum and Subsequent Meltwater Event: A Numerical Model. Journal of Geophysical Research, 101: 16 305-16 332. 
Svendsen, I. J., Elverhøi, A., and Mangerud, J. (1996) The Retreat of the Western Barents Sea Ice Sheet on the Western Svalbard Margin. Boreas, 25: 224-256.

Vorren, T. O., Lebesbye, E., and Larsen, K. (1990) Geometry and Geneseis of the Glacigenetic Sediments in the Southern Barents Sea. In: Bleil, U.and Thiede, J. , eds., Geological History of the Polar Oceans: Arctic Versus Antarctic. Kluwer Academic Publishers, 269-288.

Weinelt, M., Sarnthein, M., Pflaumann, U., Schulz, H., Jung, S., and Erlenkeuser, H., (1996) Ice-Free Nordic Seas During the Last Glacial Maximum? Potential Sites of Deepwater Formation. Paleoclimates, 3: 23-57.

Weinelt, M., Sarnthein, M., Pflaumann, U., Schulz, H., Jung, S., and Erlenkeuser, H., (1996) Ice-Free Nordic Seas During the Last Glacial Maximum? Potential Sites of Deepwater Formation. Paleoclimates, 3: 23-57.

White, F. M., Spaulding, M. L., and Gominho, L., (1980) Theoretical Estimates of the Various Mechanisms Involved in Iceberg Deterioration in the Open Ocean Environment, $U$. $S$. Coast Guard Research and Development Rep., CG-D-62-80: 126 pp. 